A publication of the Muma College of Business | University of South Florida

Volume 6

Number 15

15 JULY 2021

MICHAEL GUERIN, MATTHEW MULLARKEY, JAMIE CUDDEN

\title{
CITY TELECOMS POTENTIAL: 5G CHALLENGES FOR A SMART CITY ${ }^{1}$
}

\begin{abstract}
To unleash the potential of a smart city, Dublin should strategically position its assets and infrastructure. What is the best collaborative measure that Dublin has at hand?
\end{abstract}

Chief Executive of Dublin City Council, Owen Keegan, slowly gathered his things as he left his office on a wet and miserable Monday night. After a long meeting to review the progress of Dublin's 5G experimental testbed, he realized the City was now at a pivotal point in its journey to become a smart city.

For more than three years, Owen and the Smart City team at Dublin City Council (DCC) were aware that the latest generation of mobile technology $-5 \mathrm{G}$ - promised massive bandwidth for citizens but required the deployment of dense short-range antennas on a significant number of city assets. Various telecoms vendors, and several mobile antenna suppliers, informed the city managers that network equipment would need to be installed on as many as one in every five street lighting poles in the city. Not only would these physical assets be needed, but the installation of the new $5 \mathrm{G}$ antennas required additional inground fibre optic cabling and would likely lead to major disruptions with many road closures during the installation works.

The reality was that to-date, the city had never deployed telecoms equipment on its infrastructure. 4G antennas stood on towers or commercial buildings high above the cityscape. Owen was not sure that the city departments were even aware of the implications of this new technology and the effect it would have on operations for Electrical, Traffic, Planning, and other city services.

Owen was left to wonder, what role the city should play in the deployment of a new commercial technology. How was $5 \mathrm{G}$ integral to the mission of Dublin City Council? Who would benefit most from the access provided by $5 \mathrm{G}$ ? If city assets were essential to deployment, how should the city be involved? How would the city be compensated? Could he and his team ensure that the citizens of Dublin would ultimately benefit? Was it the city's role to trade assets for access to broader bandwidth?

${ }^{1}$ Copyright (C) 2021, Michael Guerin, Matthew Mullarkey, Jamie Cudden. This case was prepared for the purpose of class discussion, and not to illustrate the effective or ineffective handling of an administrative situation. Names and some information have been disguised. This case is published under a Creative Commons BY-NC license.

Permission is granted to copy and distribute this case for non-commercial purposes, in both printed and electronic formats. 
GUERIN, MULLARKEY, CUDDEN

\section{Engaging the Market}

Owen realized that his team "didn't know what they didn't know". Consequently, in the summer of 2017, he and Dublin City Council [Exhibit 1] decided to engage the broad cross-section of the telecoms industry to consider the options.

They used the Prior Information Notice (PIN) mechanism designed:

"With the Purpose of Inviting Market Consultation on the Provision of Broadband

Wireless Connectivity and Related Smart City Enhancements" [Exhibit 2]

Dublin City Council received submissions from 12 companies with various options to address the challenges posed in the PIN. During the process an opportunity arose to engage with Dense Air LLC, a company proposing a '5G, Neutral Host, Small-Cell-as-a-Service Model'. This was an interesting proposition which required further research, so DCC decided to engage in a 2-year '5G Testbed'. Owen's team thought that a testbed approach could be used to better understand the challenges in deploying such technology using section of the city as a testbed. The concept of a testbed was similar to and different from the typical "pilot" program approach. The goal in the testbed was to subject the hardware and software to the rigors of an actual city environment filled with people, traffic, and connected devices. And the testbed would not be a simulation, but a working system fully integrated into the cellular mobile networks over time.

Fortunately, Owen had a team of project managers working in Dublin City's Smart Docklands [Exhibit 3] able to work with the neutral host and his first call was to Jamie Cudden, the Director of Smart Dublin. [Exhibit 4] Owen also knew he would need a rigorous evaluation of a technology deployment in the city and he sought the help of CONNECT- the Science Foundation Ireland research centre for future networks and communications [Exhibit 5]. The vendor, Dense Air, would have a chance to demonstrate how this technology worked and CONNECT would have the opportunity to use the network to explore a number of research questions.

As with any good testbed, issues in the deployment of this new, innovative technology were sure to arise. Owen recognized that finding and documenting these issues would be a major function of the testbed. Sure enough, as the testbed progressed throughout the two-year project, the Smart City team in Dublin City Council uncovered a wide range of issues from the availability of power and fibre to suitability of assets, to inter-operability among carriers, and, even, to a noticeable lack of a national policy for the technology.

Over time, Owen directed the testbed team to use their experiences to draft a '5G Discussion Paper'. He wanted the paper to include work with the Ireland government on rules and regulations and work with Ireland's Electricity Supply Board (ESBn) to address the challenges on access to power.

However, on this miserable Monday, Owen had an important decision to make. The final review meeting for the 2-year testbed project with Dense Air had just finished. It was clear to him that while there had been significant progress in some areas, many of the hurdles to overcome in the next 12 months would be internal battles amongst the physical city asset managers as well as increasing external pressure from the telecoms commercial market players to get access to city assets.

This was a pivotal moment on the $5 \mathrm{G}$ journey and Owen must decide if Dublin City Council should cancel all research projects, including the testbed to avoid wasting valuable time and resources. Alternatively, they could extend the testbed to give it further opportunity to demonstrate value, or ramp up their efforts internally by increasing the resources within the telecoms team to address the increased demands from the telecoms market and DCC's ability to meet the increased expectations. 


\section{A Spectrum of Choices}

The world of telecoms was not an entirely new one to any city, but the characteristics of $5 \mathrm{G}$ made this new form of connectivity a particularly challenging one with significant implications for how a city is run and managed. Firstly, the spectrum and technology used by $5 \mathrm{G}$ differed greatly from $4 \mathrm{G}$ LTE in that the signal traveled just 300-500 meters with any reliability, as opposed to several kilometers for $4 \mathrm{G}$. The $5 \mathrm{G}$ signal was also poor at penetrating buildings and needed to be line-of-sight from antenna to antenna.

As an added complication, many of these $5 \mathrm{G}$ small cell antenna sites would require a fibre "landline" connection to the broader cellular network, but Dublin did not own fibre. Fibre connectivity was managed by a private telecom market in Ireland. Owen was concerned that if small cell deployment was left to the private market there will be multiple road closures, streets repeatedly dug up and not repaired to a high standard, and only affluent areas of the city might be earmarked for the new technology, further contributing to a digital divide for the city's citizens.

Owen also knew that another important consideration for Dublin City Council was the aesthetics of the city. With 45,000 streetlights in Dublin, many of which were considered 'heritage' poles and many in conservation areas of the city, he knew that city leaders and planners would want to avoid multiple unsightly small cells on light poles. But how would Owen manage the balance between the city's history and heritage with the expectation that Dublin was a "high-tech" city with world-class connectivity?

The structural integrity of the city's assets was a further concern. Many of the poles in the city were installed over the last 50 years with the sole purpose to accommodate a light luminaire. The proposed new $5 \mathrm{G}$ equipment could pose a risk to those assets with extra weight and wind-load that increased the likelihood of the light poles failing. "These assets were not built for this and we have no idea which ones can handle the weight, and which can't!", Owen was told at his meeting with the Electrical Services Team in Dublin City Council.

Within the Dublin City Smart City team, Owen had advisors who were well versed with the 5G testbed and the challenges he faced. One concept that the Smart City team had been considering was the idea of a 5G Neutral Host arrangement for the management of city assets with a wider deployment of 5G small cell antennas in the city. The idea of Neutral Host was not necessarily new in the telecoms market.

Neutral hosting occurred frequently in the 4G LTE antenna tower clusters where a third party owned and managed the physical (mechanical/electrical asset), but the telecom providers "owned" the communications channels and acquired spectrum. Owen thought the concept, as applied to small cell 5G clusters in the dense confines of the city streets, might be a little more challenging.

Talking with the Smart City team, Owen also found out that the term - Neutral Host - could mean many things to many people. For the city, the term seemed to suggest one antenna "box" on one pole capable of propagating the signal from all authorized telecom companies with the physical asset and the sharing of the service managed by a third "neutral" entity. This approach was in stark contrast to each telecom installing their own equipment on any given pole across the city.

\section{A Potentially Lucrative Opportunity}

While the challenges to deploy this technology were evident, the potentially lucrative opportunity for the city to be compensated for the use of its assets was not lost on Owen. If a third party were allowed access to city assets for commercial purposes, it was expected that this would be a commercial arrangement and generate revenue for the city. Dublin City had partnered with many cities through their smart city programme, and was an official 'sister city' of San Jose. Through this relationship the teams in Dublin had significant exposure to the innovative programme in San Jose which had led to the deployment of 
4100 small cells and generated revenue of over $€ 1 \mathrm{~m}$ - money the city of San Jose redeployed to reduce the digital divide [Exhibit 6]

Closer to home, some years previously, as part of a Strategic Development Zone in Dublin's Docklands, the city council decided to explore a mechanism where the city could provide fibre or access to conduit. The idea at that time was to lease access to city assets to commercial vendors. Unfortunately, this "simple" business model became increasingly complex and problematic as various vendors contested "subsidized city assets" being used "to aid" given vendors and thereby disrupt the commercial market.

The foundation was laid for Dublin City to take a leadership role in the deployment of this new, disruptive telecom technology. The pressure to move forward rapidly, equitably, and in a manner that benefited the people of Dublin was tremendous. The hurdles were equally high. Owen was grateful that he had the experience of the $5 \mathrm{G}$ testbed to consider as he evaluated the options available.

\section{A Testbed}

Dublin's 5G testbed had been a great source of knowledge generation for the city, industry partners and research institutions. Throughout the course of the 2-year project, each partner had developed a wealth of understanding and uncovered numerous challenges that would restrict any form of city-wide small cell deployment. Dublin City Council's decision to engage in a testbed with Dense Air [Exhibit 7] came about in mid-2017 after a market consultation. The two, along with CONNECT Research Centre [Exhibit 5], decided to engage in a project to evaluate the deployment process of small cells. This included outdoor deployments on city owned traffic and lighting poles in the 'Smart Docklands' testbed, and indoor, in the buildings of multinational tech partners. The goal of a testbed was to deploy a system in the actual city landscape subject to all the conditions inherent in city environment while remaining bounded and controlled as an experimental test site.

Throughout the first 18 months the DCC smart city team overcame many obstacles to create Ireland's first urban $5 \mathrm{G}$ testbed. It consisted of 21 outdoor small cells; 11 of which were on traffic lights and 10 on street lighting poles, and 6 indoor small cells placed in a range of locations such as co-working spaces and a hotel. [Exhibit 8]
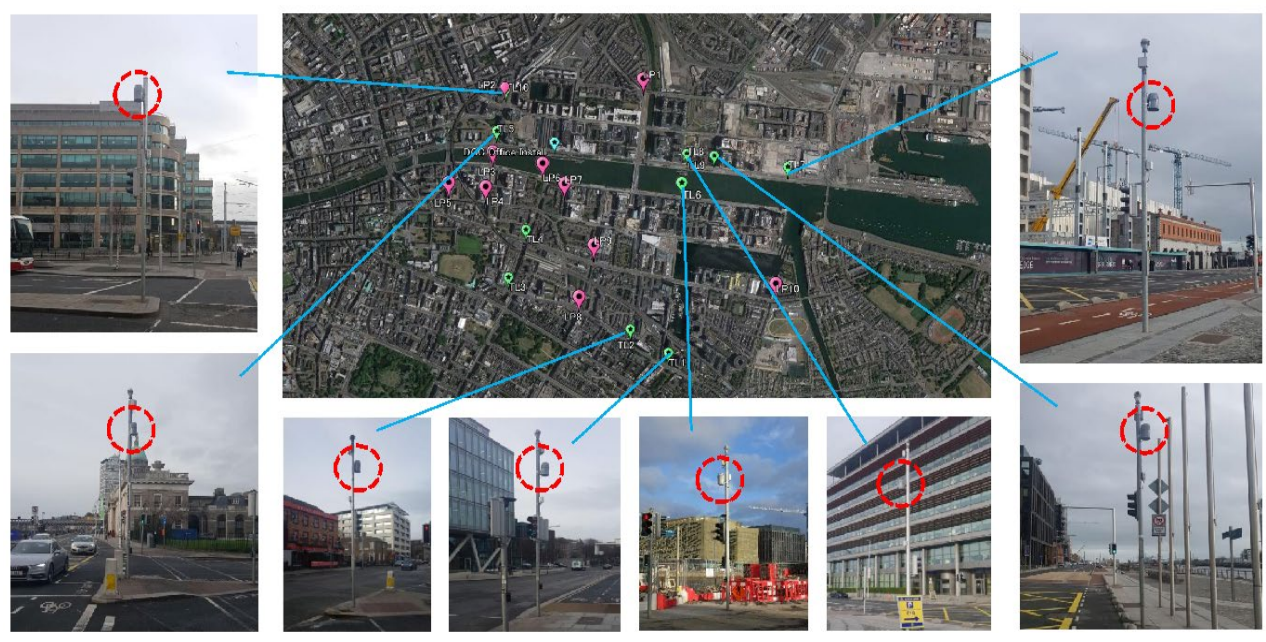

Figure 1: Example Small Cell Deployments in Dublin Docklands

Each location came with its own set of challenges and benefits (see Figure 1). For example, many traffic light poles have 24-hour power and the correct power source, however they are mostly smaller than 
public lights. The height of a public light pole is a significant benefit but many are not suitable to retrospectively mount a $7 \mathrm{~kg}$ box over 7 meters atop a pole.

The indoor locations were chosen to provide the Dense Air team with different types of challenges. One was a 199-year-old building, largely made from cast iron and glass, a second was a modern hotel with very poor cellular coverage and another was a recently constructed office with energy efficient glass which has been proven to be an issue for $5 \mathrm{G}$ propagation.

With the support of Owen, the Departmental leads in Traffic and Electrical Services, the ESB and many others, the Smart City Team for Dublin City Council sourced the relevant policy derogations to enable a $5 \mathrm{G}$ testbed with a 2-year time limit.

As Michael Guerin, the 5G project manager for Dublin City Council, quickly learned there were many pre-existing reasons why third-party equipment could not be connected to the city assets, such as:

- The city council cannot change the power tariff for lighting assets to add the power consumption of a 'small cell', the option was not available on the customer platform meaning they would not be paying for the power that was used, which, was breach of ESB policy [Exhibit 9].

- The city council cannot supply power and pass the charge onto the small cell provider as this was against national regulation which prevents the city from becoming a wholesaler of energy.

- Many assets were not structurally suitable for additional equipment.

The list of over 30 challenges to overcome was one which was new to all partners in the testbed and as Owen knew, these challenges often came with lengthy delays.

Many of these challenges required official derogations from regulators and temporary policy exemptions from partner agencies. While this accelerated the process of small cell deployment in the testbed, it often did not address all of the challenges and left many unanswered policy questions. Owen realized that the technology was just the first of many hurdles faced by widespread 5G deployment in the city.

Understanding the role the city could play in the $5 \mathrm{G}$ network deployment and operation would be critical to "hosting" this service for the citizens of Dublin.

\section{A Neutral Approach}

The primary $5 \mathrm{G}$ small cell technology option explored by $\mathrm{DCC}$ in their $5 \mathrm{G}$ testbed was a 'neutral host' network. This type of network was explained by DCC in their 5G Discussion Paper as "the deployment of a single physical small cell that can then be shared by multiple operators, particularly in a dense urban setting". DCC highlighted that there were many flavours of Neutral Host, however in DCC "we see Neutral Host as meaning the local authority working with one facilitating entity who manages only one physical small cell on a city asset."

The two other common small cell deployment models were 'Shared Infrastructure' and 'Exclusive Concession' (see Figure 2). The former was a scenario where multiple small cells were deployed on a pole, with each Mobile Network Operator (MNO) having their own equipment separate from one another. The latter was a scenario seen in many cities, where an MNO was given exclusive access to city assets for a period of time, which leads to significantly reduced competition and coverage for other MNOs. 

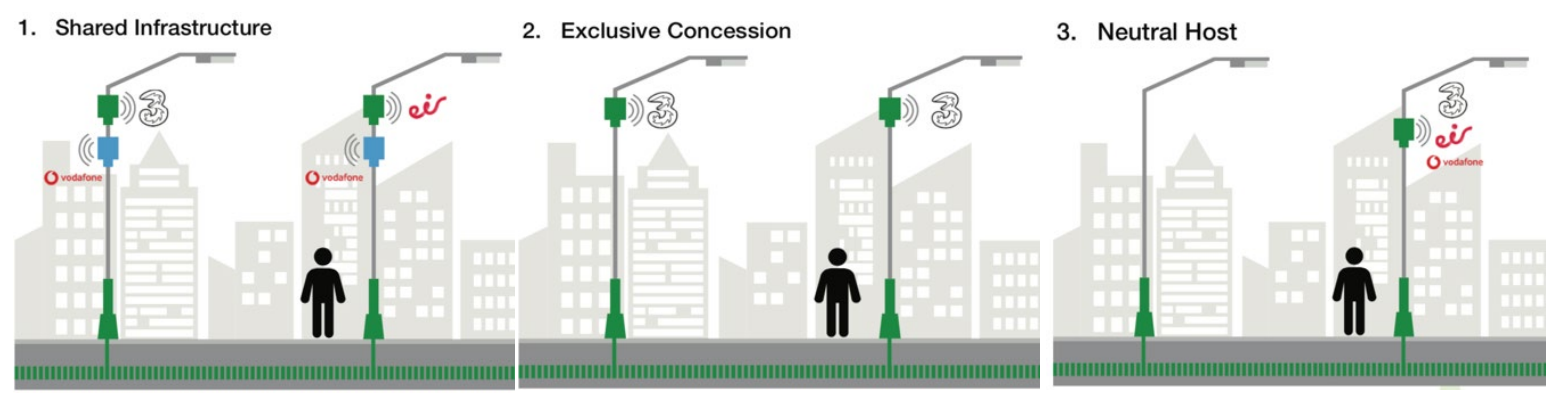

Figure 2: Small Cell Deployment Models Explained

Dublin City Council was interested in the 'Neutral Host' for many reasons:

- The much-reduced operational requirements involved in deploying one piece of equipment was far more appealing than multiple installs.

- Deploying technology which had the ability to equally distribute cellular coverage for all networks was likely to reduce the cost for deployment, ensuring better coverage across the city and access to quality internet access, thus reducing the digital divide.

- Dublin was a city with many historical areas and one single install would reduce the visual pollution.

Dublin's Smart City Programme Manager, Jamie Cudden, had been involved in many international city innovation networks, including the Harvard TECH City Innovators, which hosted their inaugural '5G CityView Accelerator' in Dublin. [Exhibit 10] Through this network, the idea of a 'Neutral Host' network had been discussed extensively and it was clear there were different types of 'Neutral Host' depending on who owned the spectrum. These were described in DCC 5G Discussion Paper as either (1) passive neutral host, i.e., multiple operator antennas in one small cell array where "sharing" occurs on each antenna, or (2) active neutral host, i.e., spectrum-based sharing at the aggregate on a core network level rather than at a small cell street level. [Exhibit 11]

Dense Air's Neutral Host model fits into the 'active' category. With backing from their parent company, SoftBank, Dense Air has purchased 5G spectrum assets in many countries including Ireland. This positions Dense Air as only one of five such companies with these assets, and the only one that aims to provide such a network. This unique scenario, coupled with Dublin City Council's reputation for fast delivery in innovation projects, ensured Dublin was chosen for the Dense Air testbed over cities such as London and Lisbon.

Whatever the flavor of 'Neutral Host', it was clear to Owen that the goal, when the technical and operational barriers were overcome, was an enhanced $5 \mathrm{G}$ network. The prospect of a pervasive $5 \mathrm{G}$ network for all telecoms across Dublin was an appealing one. Not only would this be first of its kind, but it would further enhance the reputation of Dublin as a leading tech city, and could attract further foreign direct investment (FDI) from global tech companies. This strong tech-led FDI had seen companies such as Google, Facebook, AirBnB, LinkedIn, Twitter, Amazon and others create more than 50,000 wellpaying jobs in Dublin over the last 10 years.

\section{External Factors}

In 2018, the objective of the $5 \mathrm{G}$ testbed was to deploy multiple small cells on city assets and to test the 'neutral host' attribute with at least one of the telecoms companies, of which was not determined at that time. Both of these objectives met strong external resistance which was beyond the control of Dublin City Council. First, the deployment of small cells was initially rejected by ESBn, the semi-state 
Electricity Supply Board (Networks) for Ireland. At the time of the request it was against ESB policy to permit such equipment (small cells) to be installed on local authority owned lighting poles. There were many reasons for this:

- ESBn could not split the energy bill for two assets on one pole, e.g., light and small cell.

- ESBn billing systems could not handle two unique asset IDs on one pole.

- ESBn did not have the ability to quickly adapt the large SAP database and system required to list 'small cell' as an option for billing.

- It was not possible to have two separate tariffs on one pole: down-to-dusk for the light and 24hr for the small cell.

- Some poles in Dublin were on a 'daisy chain' style installation, where the ESBn source may be up to 10 poles back, meaning there was no way of knowing the power consumption of lights versus the small cells without installing additional equipment and submetering at the pole through a pillar which can be expensive.

It was highlighted to Dublin City Council that many of these issues could not be addressed until 2022 at the earliest when the new version of the tariff and billing software at ESBn was due for an upgrade. Owen realized that if this was to remain the case, the ESBn billing system might significantly stifle the progress of any $5 \mathrm{G}$ network in Ireland.

However, in a fortunate turn of events, ESBn was tasked through the Irish National Mobile and Broadband Taskforce to write a policy document on 'installation of small cells on local authority assets' by the end of 2019. As a result, ESBn engaged with the DCC team to assist with deployment of small cells for the testbed with the aim of addressing many of these issues. For the testbed deployment, a derogation was issued for the duration of the project and it was hoped ESBn would be addressing the systemic issues during the testbed operation.

The second objective of the testbed was to test the 'neutral host' aspect of the 5G small cell network. Again, external factors led to challenges. The city-led neutral host network approach was always going to be disruptive to the market, however, it was hoped the telecoms would see a much-reduced Capital Expenditure (CapEx) for equipment installation and more pervasive coverage as a positive. Instead, the security and network integrations seemed a step too far for the Irish telecommunications companies at this stage.

\section{Internal Stakeholder Factors}

As Owen pondered his decision he reflected on an insightful and challenging three years from the market consultation Prior Information Notice (PIN) [Exhibit 2] to the end of the 5G testbed project. While so much progress had been made, he realized that there was a long road ahead before Dublin would have the $5 \mathrm{G}$ connectivity they wanted.

Jamie Cudden and the Smart City Team had been leading on this project for Owen and they were ready to see additional resources given to the $5 \mathrm{G}$ and connectivity projects to quickly address the challenges that had arisen. Their goal to make Smart Docklands 'the most connected business and living district in the world' would be further enhanced by a state-of-the-art neutral host $5 \mathrm{G}$ network. It would also provide the type of connectivity required to drive many of the future smart city use cases they would like to explore such as AR/VR, connected drones, and emergency response.

The Public Lighting team in Dublin City Council, however, saw things quite differently. They wanted smart connected lights to conserve energy and improve illumination of the city thoroughfares - but this 
was something that they knew could be provided without the complexity of $5 \mathrm{G}$ connectivity options. The headache and hassle of opening the public lighting assets for third party use was not on this team's agenda. The head of the Public Lighting department had spent several years decluttering the city's lighting poles and fixing damaged poles to provide a safe lighting network. The last thing he wanted was the nice "clean" efficient light poles "cluttered" with antenna and fibre cables.

Similarly, the Traffic Department wanted the ability to adjust lights and cameras in real-time across the city. The smooth running of the city traffic system was paramount and if the addition of third-party equipment would interfere with this operation, then it was not in the interest of the traffic department to support a change. There was also an ongoing battle for access to these prime assets as they have $24 \mathrm{hr}$ power and many have fibre, but why open the assets for this?

In contrast, Irish telecoms companies realized that they did not need access to city assets now but would in the next two years. Their $5 \mathrm{G}$ plans began with an upgrade of macro sites on rooftops and their street levels plans would come next. Change would come and DCC would need to be prepared to manage the inevitable influx of requests both from an operational and planning standpoint.

The neutral host providers wanted to see the changes made as soon as possible. Many had made a gamble of the timing of the requirement of street level small cells and it was in their interest to see things move at pace. They also had limited examples of successful similar deployments from around the world so both the network and deployment models coupled with new business models were still not clear to Owen.

Key external players such as ESBn were in an awkward position. On the one hand, their obligation as ESBn (Networks) should encourage them to fast-track the changes needed. On the other hand, Ireland's ESBn were not connectivity experts and this was not their core business. They already faced technology pushes for smart grids and the addition of renewable energy sources. 5G small cells deployments were understandably not at the top of the ESBn priority list. This coupled with their sister company ESBt (telecoms) having a keen interest in the telecoms market meant that the timing of the decisions might not be as DCC desired.

The Irish government was also in a strange position. There was a much-publicized procurement predicament it had experienced when trying to develop a National Broadband Plan. The plan had promised fibre connectivity to all homes in Ireland, but execution of the plan had thus far failed to meet the promise. With just one vendor left in the process of executing that plan, as the others had publicly pulled out, and with costs running $3 \mathrm{x}$ the projections, the idea of another plan for the new $5 \mathrm{G}$ technology deployment was seen as a less than desirable discourse. [Exhibit 12]

Owen was also aware that the Dublin 5G testbed had been well publicized on the global smart city stage; cities from across the world were watching Dublin to see what decision they would make for deployment and business models.

The potentially lucrative opportunity was clear to Owen, but the mechanism was not. With very limited international examples to learn from, Dublin would need to carve a path for itself. In general, the business model options varied based on the decisions to be made by the city leadership. For example, would the city own the lighting, traffic, assets, fibre, or ducting? Would DCC want to manage the deployment or outsource to a third party? What would the city do as more innovative models emerged that would benefit local authorities, MNOs, small cell operators and all involved in the deployment of telecoms equipment? 
As the technology was relatively new, the year 2020 will be the first-year cities engaged the market on a wide-scale. Suddenly, cities might create even more innovative models for entities to manage all wired and wireless telecoms on their behalf. The most popular public-private business models thus far were:

- Special Purpose Vehicle (SPV) or Join Venture (JV) - In this model the local authority created a legal entity with a small cell provider, usually a neutral host provider, and this entity managed the operational roll out of small cells. Typically, the local authority's contribution to this model was its assets, and in some cases it might provide additional funding.

- Concession Model - In this model the local authority would consult the market and choose one third party entity, either small cell provider or MNO, to grant access to their assets. This was often done on an exclusive basis, reducing the level of competition in cities.

- Lease Agreements - This model was used in San Jose where the local authority granted multiple MNO's access to individual assets on a lease basis.

\section{The Decision}

Owen now had to make his decision on the future telecoms plans for Dublin. He needed to balance the internal needs and concerns with the external requirements and challenges. His decision would likely impact the availability of high-speed mobile telecom and internet access for citizens of Dublin for 5-10 years to come and the nature and type of revenue streams which might (or might not) be generated.

The first option for Owen was to end the testbed project in January 2020 as originally planned. Owen could have Dense Air remove the equipment, and let the market decide how they want to approach small cells over the next few years. This would leave Dublin City Council in a potentially weaker position when it came to understanding the benefits and opportunities for them but given the uncertainty it would reduce the risk of further investment which may not prove to be fruitful.

The second option was for Owen to have the Smart City team extend the testbed project for one more year. This would provide Dense Air with an opportunity build relationships with key external players to demonstrate the power of the neutral host equipment. There was a risk that it would be an additional twelve months with no further use of the testbed, while still funding the resources to manage it. Or it might lead to a world-class demonstration of 'neutral host' and some 5G use cases which have not been explored before. DCC would also have an opportunity to improve the internal factors.

The third option was to increase the 5G and telecoms resources. In this option, DCC would hire dedicated staff to further assist the smart city team in engaging the market on $5 \mathrm{G}$ solutions. This option would be more costly but may provide additional revenue in the long term if managed correctly. Additionally, increasing the telecoms teams' capacity might enable the DCC to pursue additional 5G projects and provide more insight into the potential best solution. However, with the internal reluctance from some departments and the external variables that DCC had little influence upon it may result in time and money wasted. And, how would Owen supplement the team with expertise at a cost that was affordable on tight city budgets?

One thing was for sure in Owen's head, this was a pivotal point in the journey to becoming one of the most advanced cities in terms of connectivity and citizen access, but it would not come without risk, a level of risk that he realized was not typically associated with public sector or local authorities, but one that may be required if DCC were to create the game changing network many desired. 


\section{Acknowledgements}

The authors wish to acknowledge the Fulbright Commission and Lero Science Foundation Ireland for their support of the Fulbright Core Research Award that supported Dr. Mullarkey's work with Dublin City Council, National University of Ireland Maynooth, and Trinity College Dublin. 


\section{Exhibit 1: Dublin City Council}

Dublin City Council is the democratically elected body that governs Dublin City. We are the largest Local Authority in Ireland.

In this section, you can learn more about how we are organised and about the services we provide to you.

You can obtain a wide range of information and services from Dublin City Council:

- Business services, e.g. licences, permits, rates

- Community Services e.g. community grants

- Culture and Economic Services, e.g. libraries, sports \& fitness centres, Local Enterprise Office

- Emergency Services e.g. Dublin Fire Brigade

- Environmental services, e.g. litter, noise

- Housing services, e.g. maintenance, housing list

- Planning services, e.g. applications, objections, conservation

- $\quad$ Roads \& transport services, e.g. traffic updates, parking

Source: http://www.dublincity.ie/main-menu-your-council/about-dublin-city-council 


\section{Prior Information Notice (PIN) \\ With the Purpose of Inviting Market Consultation \\ Contract Type: Provision of Broadband Wireless Connectivity and Related Smart City Enhancements}

Dublin City Council through its smart city function is promoting a number of so called "smart city" initiatives, partnering with academic institutions and private organizations to improve quality of life, deliver more efficient and responsive city services and increase engagement with citizens.

Recognising that connectivity is becoming a critical element of infrastructure for a smart city, the City Council is keen to provide free wireless connectivity to businesses, residents, visitors etc. which will be accessible at key locations in the public domain. All such connectivity must be provided free of charge, and meet expected demand for data over the lifetime of the platform. The technology should support gigabit broadband wireless connectivity, including WiFi, LTE and emerging "5G" connectivity technologies, many still under development. Backhaul should be by means of fibre so as to be futureproofed and upgradable. Consideration should also be given to the integration of solutions into city assets and on street infrastructure / furniture. All facilities should be designed to support the hosting of equipment and services from any and all telecommunications operators (shared service). The project should be able to be delivered with no operating cost to Dublin.

Please note that this is not a call for competition and no tender documents are available at this stage. Also this process will not be utilised in order to preclude any future competition to be conducted by Dublin City Council.

Without prejudice to competition in the market places, the purpose of this market consultation will be to examine and consider the various technical and commercial options which might present themselves through a competitive tender process to be advertised in the near future.

The market consultation may also assist Dublin City Council in the development of the procurement strategy for any subsequent competition.

RESPONSES BY EMAIL ONLY -

Interested parties should respond before 12 noon on Friday 16/06/17 to jamie.cudden@dublincity.ie by supplying the following information:

- Company Name

- Contact Name

- Contact details - phone, email

- Website

- Background information on company

- Details of solutions provided in other locations, whether in Ireland or internationally

It is anticipated that Dublin City Council will enter into a market consultation with a selection of parties at Dublin City Council's sole discretion. Following this consultation, Dublin City Council intends to publish a call for competition in due course on www.etenders.gov.ie and in the Official Journal of the EU 


\section{Exhibit 3: Smart Docklands}

Smart Docklands is a unique world-class smart city testbed in the heart of Dublin's Docklands area that provides innovators and the municipality an opportunity to fast-track innovation in an urban environment. It was funded in April 2018 for 2 years with a total of $€ 600 \mathrm{k}-€ 300 \mathrm{k}$ from each of Dublin City Council and Connect/Enable. Smart Docklands has seen a multiple of over 10x on the city's investment through further EU funding, economic growth and global exposure.

The Docklands area is a $2 \mathrm{~km} 2$ in Dublin City Centre. It is the central business district (with 500 businesses), home to 26,000 people, with over 44,000 working here (11,000 from Google and Facebook alone), and contributes to 9\% of Ireland's GDP. The Docklands area also has a high concentration of new buildings and a wide range of connectivity, transport modes, and 'smart' assets.

\section{Context:}

- The technology landscape has changed drastically in the past ten years with advanced computing becoming more visible in daily life. Disruptive technologies such as Artificial Intelligence (AI), Big Data, Machine Learning and the Internet of Things (IoT) has led to the creation of Smart Docklands. It has established new ways of working with stakeholders to drive and fast track the implementation of smart technologies and policies that will make our capital more sustainable, efficient and engaging for residents and visitors alike, all with top level support from Dublin City Council to implement change.

\section{Challenges:}

- The internal operations environment into which Smart Docklands was introduced lacked anyway for tech and non-tech stakeholders to work together. Before Smart Docklands, there was no appetite for innovation, no way to fast track deployments, no way of working with small businesses, as well as larger firms with innovation departments. Its operational environment worked in silos.

- Public sector innovation is very limited largely due to strict procurement rules. This means that startups and SMEs (small and medium sized enterprises) have no way of working with local authorities. If they do, it takes years to eventually get an innovation deployed.

\section{Objectives:}

- Smart Docklands uses an innovative 'honest broker' model that acts as a catalyst to promote innovation in a testbed environment as well as establish an ecosystem of key influencers from industry, academia and the municipality. Smart Docklands facilitates and enables the testing and trialing of smart city solutions by identifying real local challenges and working with diverse stakeholders to come up with lasting solutions in areas such as disruptive technology, environmental monitoring, waste management, and smart mobility.

- Smart Docklands helps facilitate the economies' growth by increasingly driving tech inspired innovation and entrepreneurship that in turn will attract businesses and jobs, create efficiencies and raise the productivity and competitiveness of the public and private sectors. Goals:

- Through collaborative effort, Smart Docklands not only has the ability to transform Dublin City and improve the lives of those who live and work in the Docklands, but also provide solutions that can be scaled globally. 
- Our goal is to not only improve the quality of life, commerce, and productivity in the city but to accelerate the development of disruptive technologies that will make life better for people who live in urban centres across the globe.

- We are currently helping progress 3 further 'smart districts' across Ireland (Smart DCU and Croke Park, Smart Sandyford, Smart Cork Gateway) that build upon the Smart Docklands model.

- Smart Docklands works with citizens and employees of Dublin City Council that know the problems in the city, and with academia and industry to solve these problems. By playing lead facilitator managing differing expectations, budgets and speed of innovation, Smart Docklands is able to fast track deployment of prototypes in the Docklands area. This is a rare and unprecedented concept that has yet to see seamless implementation in other cities across Europe and the globe. 


\section{Exhibit 4: Smart Dublin}

Smart Dublin is an initiative of the four Dublin Local Authorities to engage with smart technology providers, researchers and citizens to solve challenges and improve city life. We aim to position Dublin as a world leader in the development of new urban solutions, using open data, and with the city region as a test bed.

Smart Dublin is delivering a programme that encourages the creation of solutions to address city needs. It has an emphasis on using the opportunities offered by emerging technology and public data. Smart Dublin has identified mobility, environment, energy, waste and emergency management as priority challenges.

\section{Objectives}

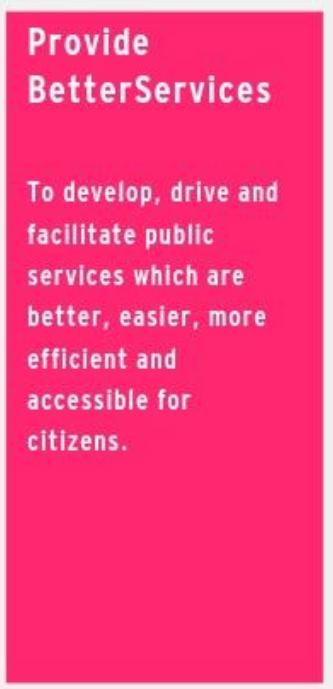

Promote

Innovative

Solutions

To provide new,

innovative and better

solutions to existing

and future challenges

which impact our

citizens, businesses

and visitors.

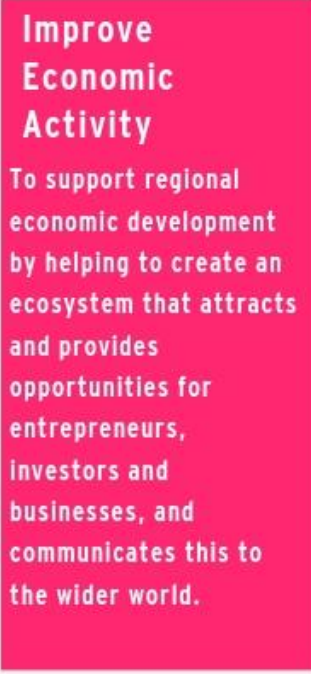

\section{Increase}

Collaboration

\&Engagement

To create effective

internal and external

collaborations and

partnerships with

local authorities,

other public sector

organisations,

academia, external

agencies, businesses,

citizens and

international

partners. 
GUERIN, MULLARKEY, CUDDEN

\section{Exhibit 5: CONNECT Research Centre}

CONNECT - the Science Foundation Ireland Research Centre for Future Networks and Communications

\section{What is CONNECT?}

CONNECT is the world leading Science Foundation Ireland Research Centre for Future Networks and Communications. CONNECT is funded under the Science Foundation Ireland Research Centres programme, which has established a network of SFI Research Centres focusing on key research areas in Ireland. The centre is co-funded under the European Regional Development Fund.

CONNECT brings together world-class expertise from ten Irish academic institutes to create a one-stopshop for telecommunications research, development and innovation. We engage with over 35 companies including large multinationals, SMEs and start-ups.

The CONNECT project code is 13/RC/2077.

The CONNECT Governance Committee is chaired by John Travers. Members are: Helena Acheson (C3 Solutions), Julie Byrne (Bell Labs/Alcatel-Lucent), Leo Clancy (IDA), Willie Donnelly (President, Waterford Institute of Technology), Linda Doyle (Dean of Research, Trinity College Dublin), Carol Gibbons (Enterprise Ireland), Isolde Goggin (Competition and Consumer Protection Commission), Cian Ó’Mathúna (Deputy Director, CONNECT), Ray O’Neill (Vice President for Research and Innovation, Maynooth University), Cormac Sreenan (Deputy Director, CONNECT).

The members of the CONNECT Scientific Advisory Board are: Gerhard Fettwies (Professor and Vodafone Chair Mobile Communications, TU Dresden), Manfred Hauswirth (Professor, TU Berlin, and managing director of Fraunhofer Institute for Open Communication Systems (FOKUS), Germany), Danny Raz (Professor, Technion, Israel, and first Director of Bell Labs Israel), Jan Rebaey (Donald O. Pederson Distinguished Professor, University of California Berkeley, USA), Jeff Reed (Willis G. Worcester Professor of Electrical and Computer Engineering, Virginia Tech, USA), Dominique Schreurs (Professor, KU Leuven, and chair of Leuven Centre on Information and Communication Technology, Belgium), Dimitra Simeonidou (Professor of High Performance Networks, and Director of Smart Internet Lab, University of Bristol, UK).

The members of the CONNECT Industry Advisory Board are: Martin Curley (Chief Information Officer, HSE), Declan Ganley (Chairman and CEO, Rivada Networks), Zelia Madigan (Deputy CEO and CCO, Equiendo), Deirdre Mortell (CEO, Social Innovation Fund Ireland), Simon Saunders (Access Technology Principal, Google), Frank Smyth (Co-founder and CEO, Pilot Photonics).

Source: www.connectcentre.ie 


\section{Exhibit 6: San Jose 5G}

5G was Officially in San Francisco and San Jose. But Who Really Had Access?

The California Report

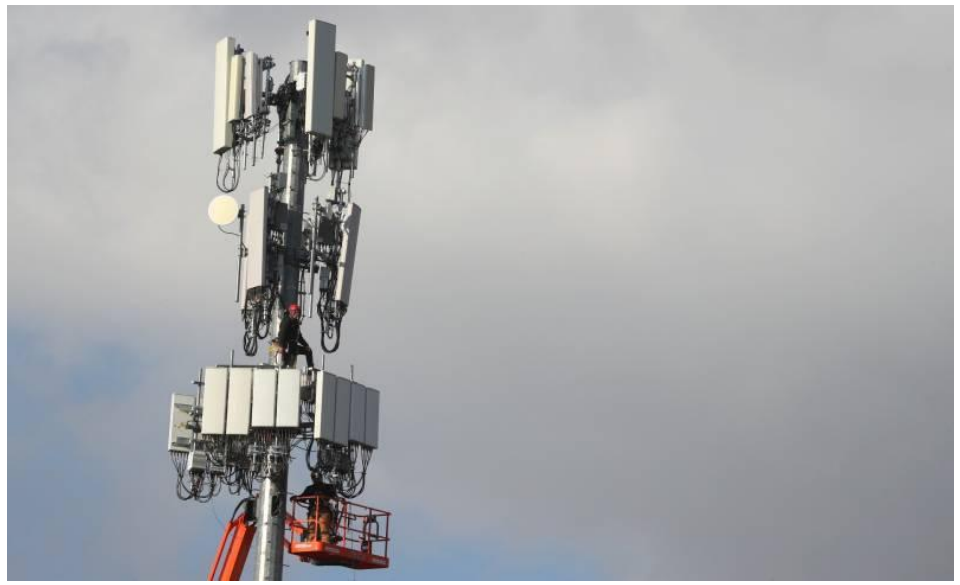

Workers rebuild a cellular tower with $5 \mathrm{G}$ equipment. San Jose's deal with mobile companies to launch 5G networks ensures that the new technology will be available to all of its residents. (George Frey/Getty Images)

If you live in San Francisco or San Jose, congratulations, you were now technologically ahead compared to most other cities. AT\&T announced that its $5 \mathrm{G}$ network went live in those two cities on Friday, making it the first mobile carrier to bring the service to widespread parts of the Bay Area.

There was a lot of hype surrounding 5G. It's been touted as a game changer cellular network with "blazing fast" speeds that can be up to ten times faster than the 4G LTE network most use now. Eventually, it will mean crystal clear video streaming or autonomous vehicles that have quicker reaction times than humans.

But as this quicker and newer technology was rolled out in more areas, some communities could be left behind.

"The number of $[5 \mathrm{G}]$ deployment and adoption in urban high-income areas was significantly outpacing those in low-income and rural areas," said Brandie Nonnecke, founding director of UC Berkeley-based tech research institute CITRIS Policy Lab. "While 5G networks hold great potential, we have to think about actionable steps that cities should be taking to ensure the deployment of these new networks were inclusive of everyone in the community."

This attitude especially rings true for San Jose, where 95,000 people already have no access to the internet, according to a recent city study. But over the past year, the city had been working to address this issue of equitable technology access. Its approach was unique among other cities working to roll out $5 \mathrm{G}$, according to San Jose's Chief Innovation Officer Shireen Santosham. 
The city's plan works by charging for permits on utility poles that mobile companies need to use as they race to build out their 5G networks. Then the city takes this revenue and reorganizes staff to permit these companies faster. The rest of the money goes towards the city's Digital Inclusion Fund, which was launched in February 2019 and aims to connect 50,000 households to the web and equip residents with digital literacy skills over the next ten years.

'The number of $[5 \mathrm{G}]$ deployment and adoption in urban high-income areas was significantly outpacing those in low-income and rural areas.'CITRIS Policy Lab Founding Director Brandie Nonnecke

San Jose currently had tiered pricing for these treasured utility poles and other public sites, charging telecoms anywhere from $\$ 750$ to $\$ 2500$ a site based on how much of the city a carrier wants to serve.

Santosham said companies essentially get a discount for choosing to serve the entire city.

"We looked at where in the city carriers were going to build and we tried to balance that across the city to the degree that we could influence it," said Santosham. "Overall, the deployment that we'll see in San Jose was going to be pretty equitable across the whole city."

So far, San Jose had permitted 943 sites and expects about 3,000 more to be developed over the next several years. Santosham said she expects the city to have the largest $5 \mathrm{G}$ deployment in the country.

An exact number of how much the city had made off the build out to date was not yet available, but Santosham said San Jose expects up to \$24 million to be raised over the next decade for the Digital Inclusion Fund.

Although the city had come up with a novel way to make sure all of its residents can ride the 5G wave, the Federal Communications Commission was not keen on seeing other communities do the same thing. It wants to keep $5 \mathrm{G}$ construction costs as low as possible for telecoms to help ensure a swift move to the new technology.

Last fall, the FCC capped the amount cities can charge for the use of public infrastructure to $\$ 270$ and imposed a "shot clock" of up to 90 days for cities to issue permits. Three mobile companies were honoring a prior agreement with San Jose that allows the city to still charge more than the FCC's mandate. 


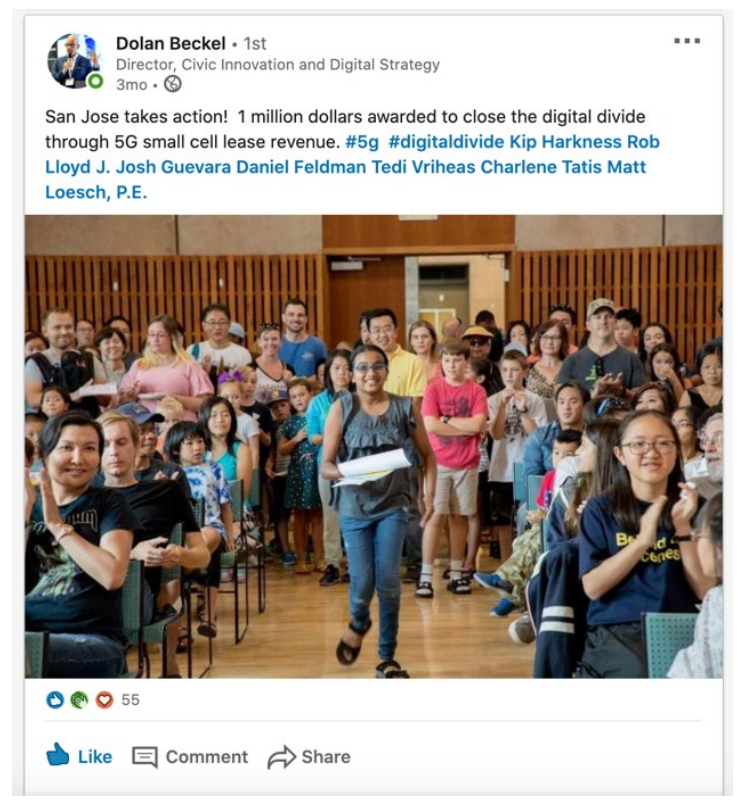

The FCC rules prompted a lawsuit from San Jose and a group of close to 100 other cities that allege the order limits cities' local control. The case was currently awaiting a hearing date in the Ninth Circuit Court of Appeals.

Still, Brandie Nonnecke at CITRIS Policy Lab said other cities should look to San Jose as a model.

"This digital inclusion fund was an excellent effort to better ensure that when we're moving to these new generations of technologies, we're doing so in a way that ensures every member of your city was able to have access," said Nonnecke.

And as for access to AT\&T's faster network that launched this week, you really can only get it if you have a fancy, new $5 \mathrm{G}$ compatible phone.

\section{Sources:}

The California Report

https://sanjosespotlight.com/san-jose-mayor-leads-municipal-opposition-of-fcc-mandate/

https://www.sanjoseca.gov/your-government/department-directory/office-of-the-city-manager/civicinnovation/broadband-strategy-and-small-cell-deployment-5147 


\section{De $n$ s e A ir 5G "Neutral Host" Densification}

D e n s e A ir targets 5G "Neutral Host" deployment use cases

- "Indoor Tower Company" plus Private and Smart City Networks

- Services delivered by "Neutral Host" shared RAN supporting multiple network use cases

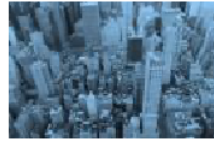

Mobile Network Enhancement (Indoor Tower Co.)

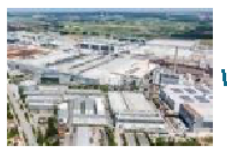

Private Mobile

Networks for Industry 4.0

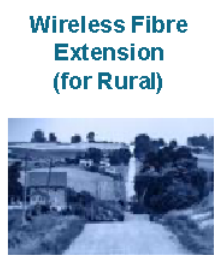

Private Wide-Area Networks (Transport)

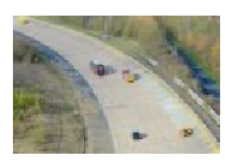

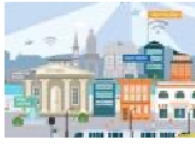

Smart City Connectivity (IoT)

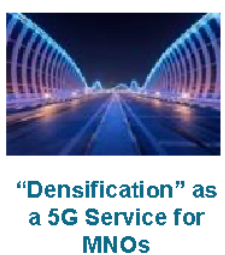
MNOS
De n s e $A$ ir

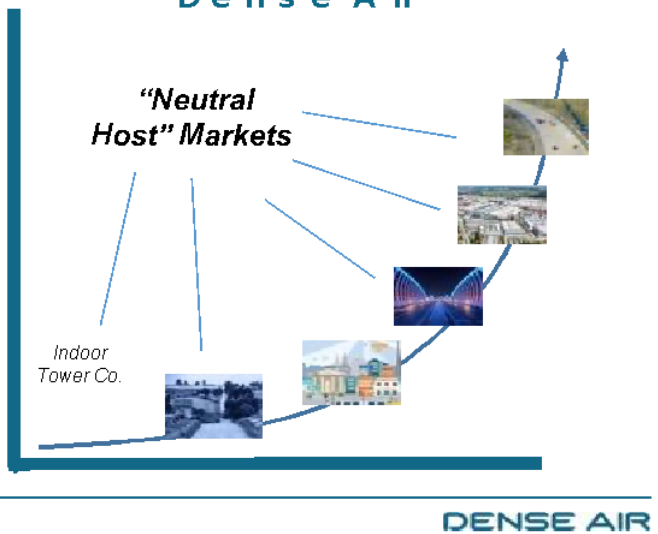

\section{D e n s e A ir - The Small Cell Network Operator}

- "Network Densification or Network Extension" as a service

- Designed for 4G LTE networks and soon for 5G "New Radio"

- Filling-in Coverage holes and Capacity weak spots in Mobile Networks

- We improve existing 4G Macro Cell Networks

- We support Private 5G for IoT, Industry 4.0, Large Enterprise and Government

- We DO NOT compete with "Retail" or "Wholesale" Mobile Service Providers

- Solutions based on operating small cells in licensed spectrum

- Our services are suitable for Urban, Suburban or Rural areas

\section{- SoftBank}




\section{MOBILE NETWORK DENSIFICATION}

We provide a service in a dedicated licensed spectrum, distinct and separate from macro networks. We dramatically enhance and extend the mobile network by filling in coverage holes and capacity weak spots and increasing spectral efficiency.

\section{WIRELESS BROADBAND}

Using small cells, we can wirelessly extend existing fibre networks to home and business in rural areas where fibre deployment is not economical nor physically possible.

\section{PRIVATE MOBILE NETWORKS}

We can provide private mobile networks and IoT networks to enterprise and industry customers. This provides enhanced security and pervasive connectivity to enable smart services and machine-to-machine communications.

\section{DEPLOYMENT USE CASE EXAMPLES}

Small Cells can be deployed in place of traditional macro sites, to improve network coverage and capacity in a more efficient and cost-effective way.

- Small Cell Rural Extension

- DAS Alternative

- Special Events

- Macro Exhaustion

- Private Mobile Networks

- 3 G Small Cell Replacement

- Copper Replacement

- Network Enhancement

\section{A MANAGED SMALL CELL SERVICE}

Our Managed Small Cell Service infills coverage holes and capacity weak spots in existing mobile networks, resulting in improve network performance, reducing customer churn rate and improving customer quality of experience

Source: https://denseair.net/what-we-do/ 


\section{Exhibit 8: The 5G Docklands Testbed with Dense Air}

\section{Targeted Small Cell Deployment Analytics}
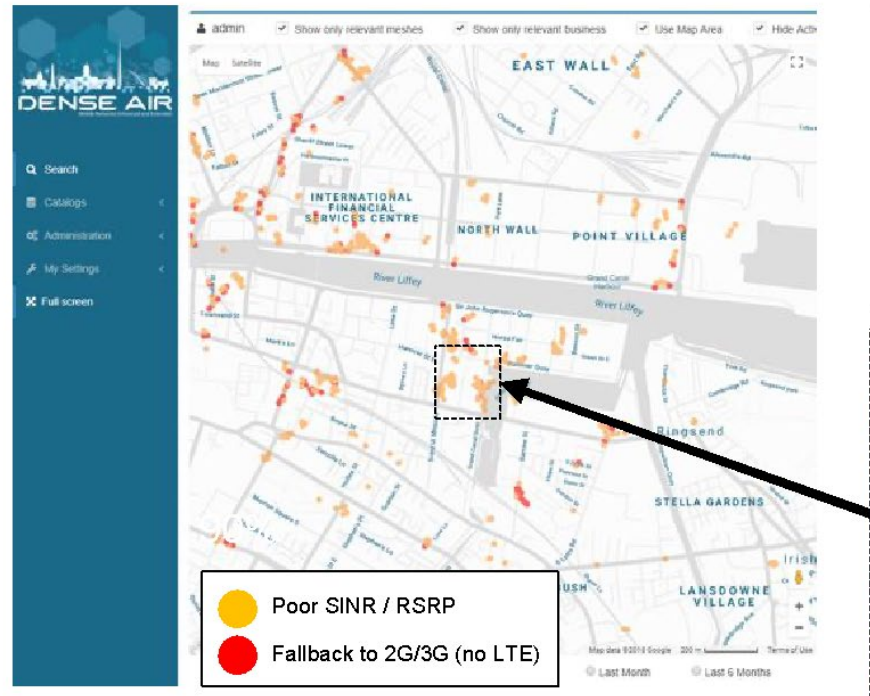

Big Data Analytics and Visualisation

- DenseWare is the De $\mathrm{n} s$ e A ir Portal

Shows MNOs and other users the probability of $4 \mathrm{G}$ LTE Network failure

- Failure Meshes provided on "building by building" basis

- DenseWare is our "Shop Window" for selling our managed service

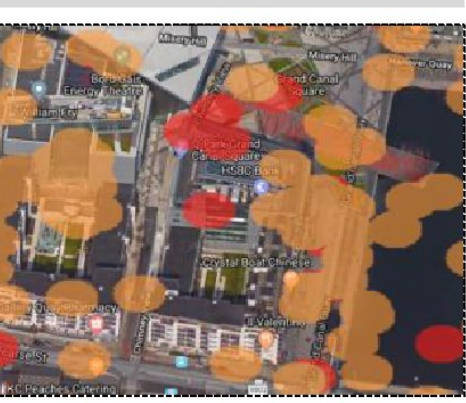

DENSE AIR

\section{Dublin City: Big Data Analysis}
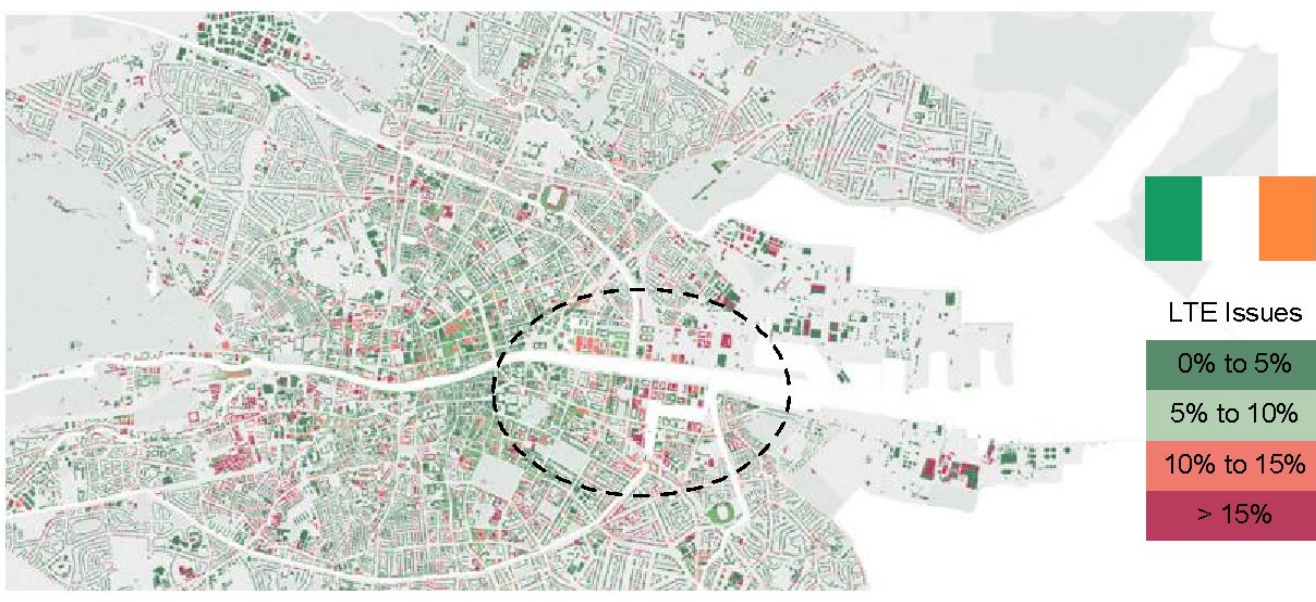

LTE Issues

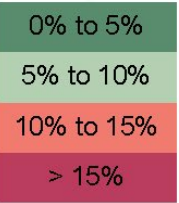

$19,142(27 \%)$ of buildings in Dublin have poor 4G LTE 


\section{Three Layer Connectivity Network}

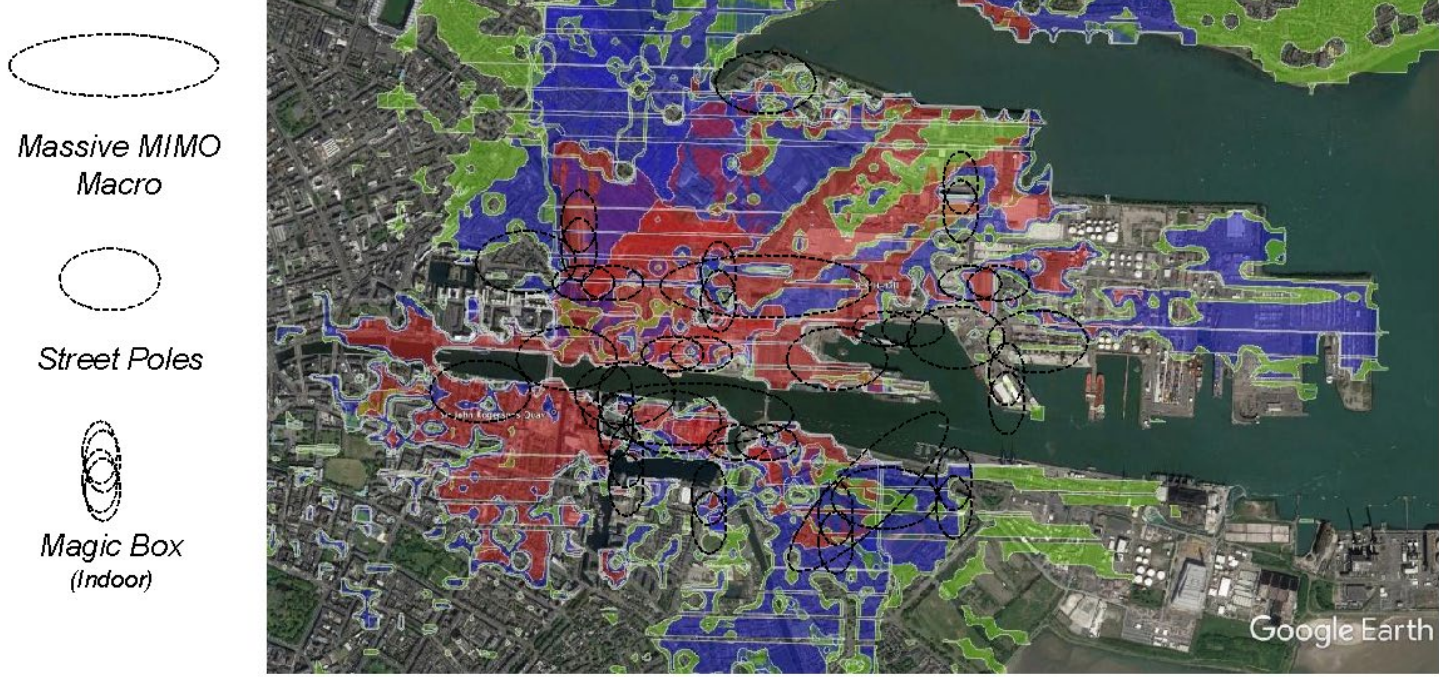

DENSE AIR

\section{Macro Massive MIMO Dense Air Relay Deployment}
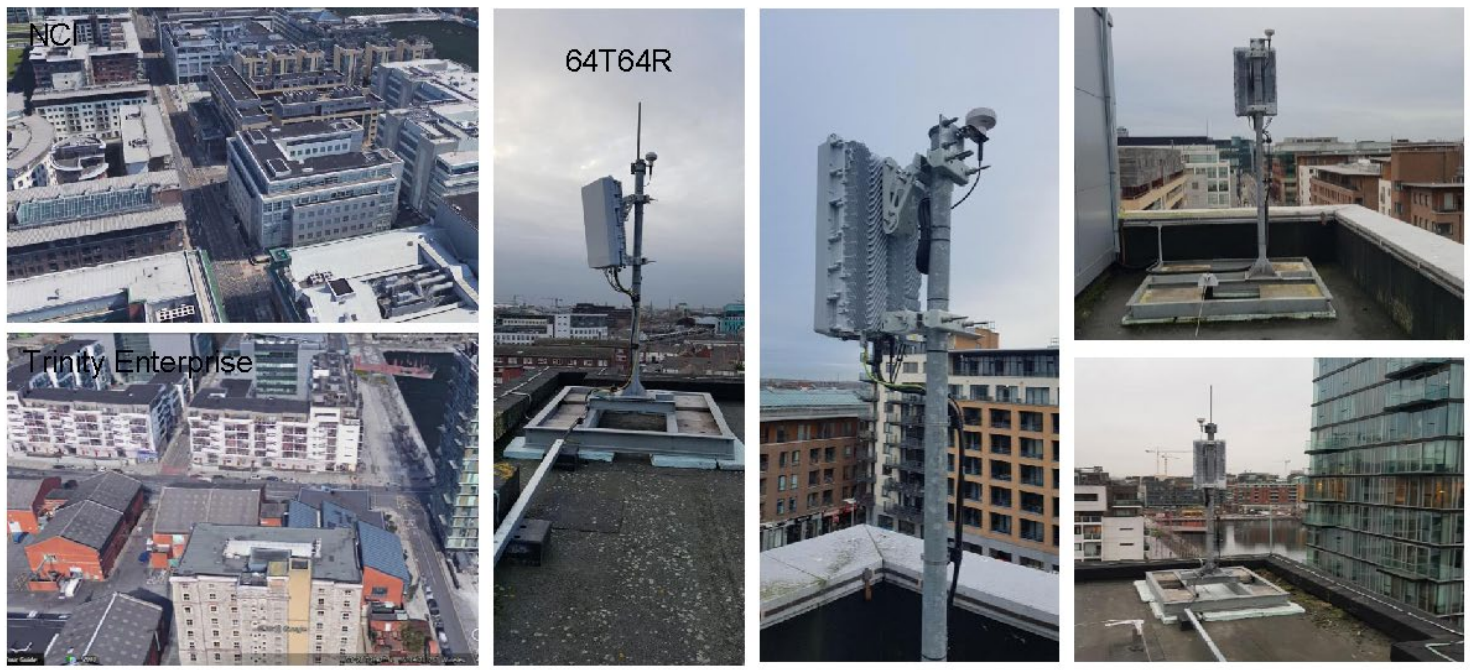

DENSE AIR 


\section{Typical Outdoor Dense Air Small Cell Deployment}

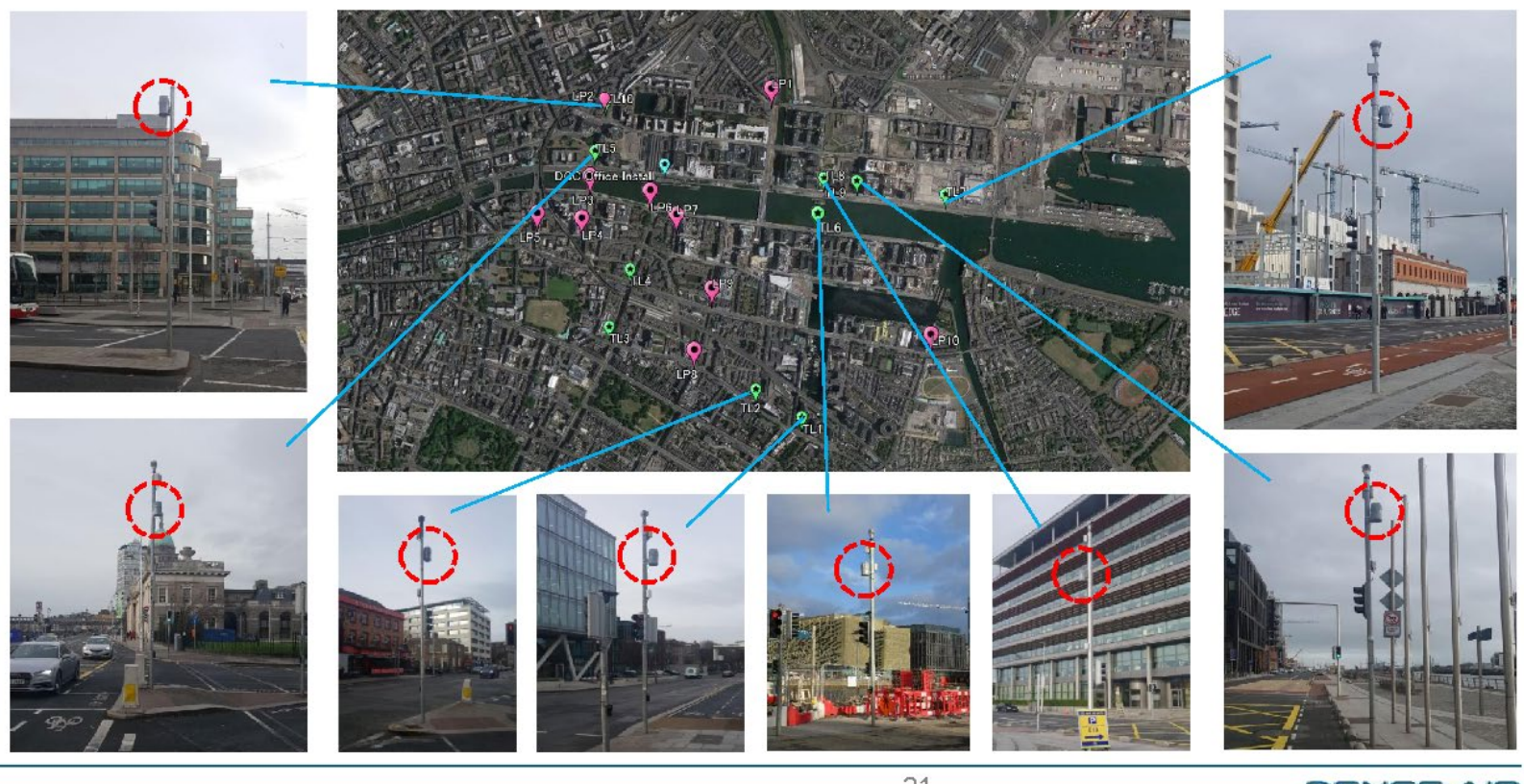

21

DENSE AIR

Typical Indoor Dense Air Small Cell Deployment
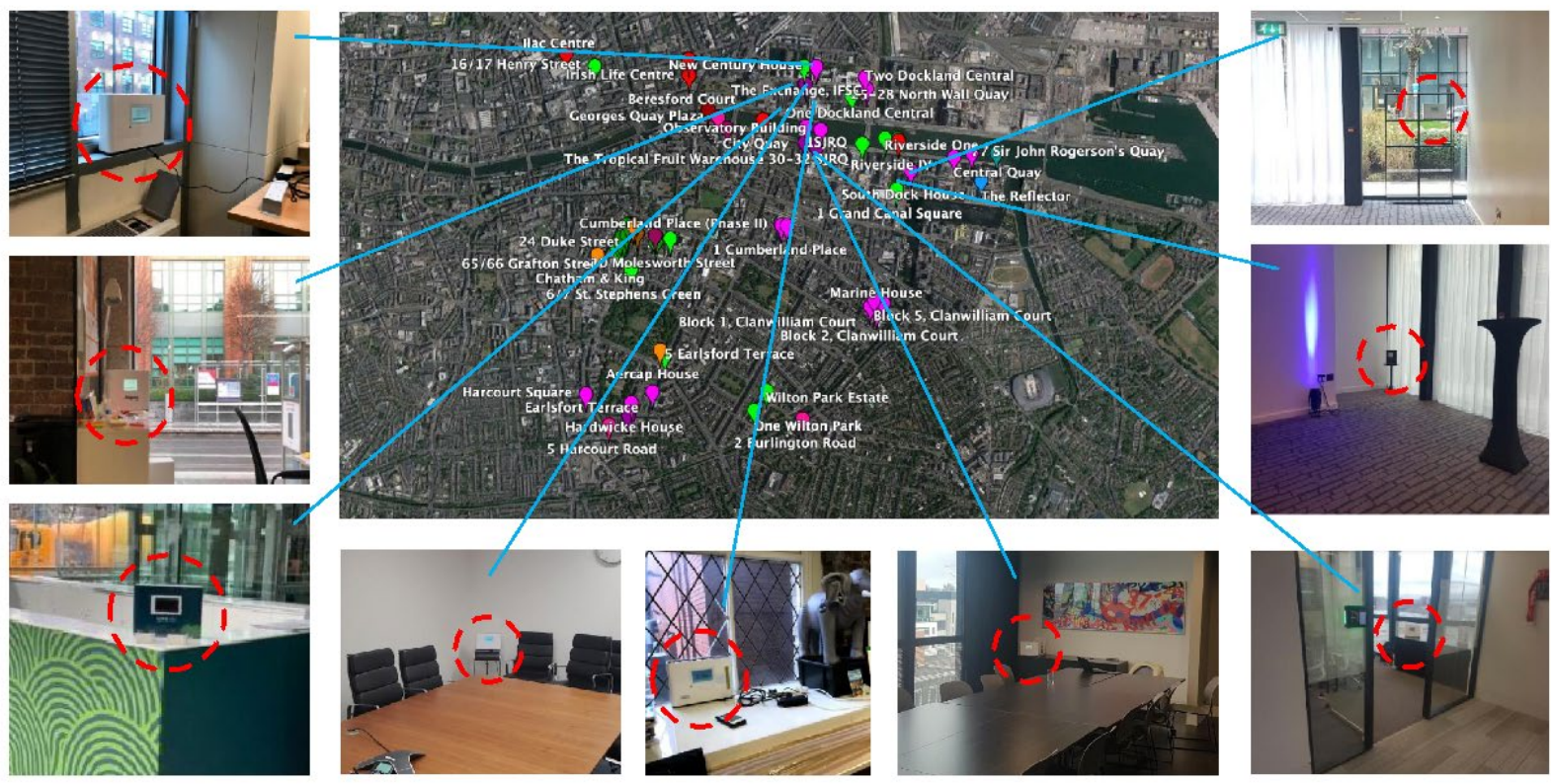

22

DENSE AIR 


\section{Exhibit 9: ESB Policy}

\section{Connect unmetered public lighting less than 2 kVA}

Unmetered public lighting connections are provided by ESB Networks where loads are less than 2kVA and energy usage is predictable. The following are the steps for Local Authorities or for

Builders/Developers wishing to connect public lighting and unmetered loads of less than $2 \mathrm{kVA}$ (Kilovolt-Amperes) to the electricity network.

Step by Step Guide

Step 1 - Get an Ordnance Survey Map and Site Plan

Step 2 - Apply

Step 3 - Receive an acknowledgement

Step 4 - Establish Group Meter Point Reference Number (GMPRN)

Step 5 - Receive a quote and Supplementary Agreement

Step 6 - Make a Payment and return the Supplementary Agreement

Step 7 - Publish details on the designated website

Step 8 - Register with an Electricity Supplier

Step 9 - Complete Wiring Certificate

Step 10 - Confirm Ducting Installation and Go Live

Multiple Unmetered Connections

Sometimes business customers and farms require multiple unmetered connections less than $2 \mathrm{kVA}$ for items such as:

- $\quad$ Traffic Lights

- Bus Shelters

- Telephone Kiosks

- TV Boosters

- $\quad$ Electric Fences

Exclusions

Under current Electricity Supply Market rules, the following loads are excluded:

- Loads in excess of $2 \mathrm{kVA}$ or seasonal loads (such as festive lighting) - these loads require metered connections and are processed as commercial connections.

- New loads with different load profiles - these loads can not be connected to the same connection point e.g public lighting with a dawn-to-dusk profile and traffic lights with a 24 hour profile. Each profile requires a separate Technical Meter Point Registration Number (TMPRN). 


\section{Exhibit 10: Harvard TECH City 5G CityView Accelerator}

\section{ABOUT THE EVENT}

5G is truly upon us and rolling out this year in many areas of the globe. The technology is constantly evolving as are the policies and impact on governments and citizens. At this Accelerator, convened by the Technology and Entrepreneurship Center at Harvard and hosted by Dublin City Council, heard from global experts on $5 \mathrm{G}$, including leading academics, industry experts and cities like your own, who have or will be rolling out $5 \mathrm{G}$ pilots and platforms.

The Smart Cities Innovation Accelerators are co-developed by the Fellows from the Technology and Entrepreneurship Center at Harvard along with city leaders and industry expert partners. During the event, attendees engaged in informative case studies, peer-to-peer problem-solving sessions, hands-on and topical workshops \& exercises designed to help you evaluate your current state and develop a plan to make your community an innovation leader for the future.

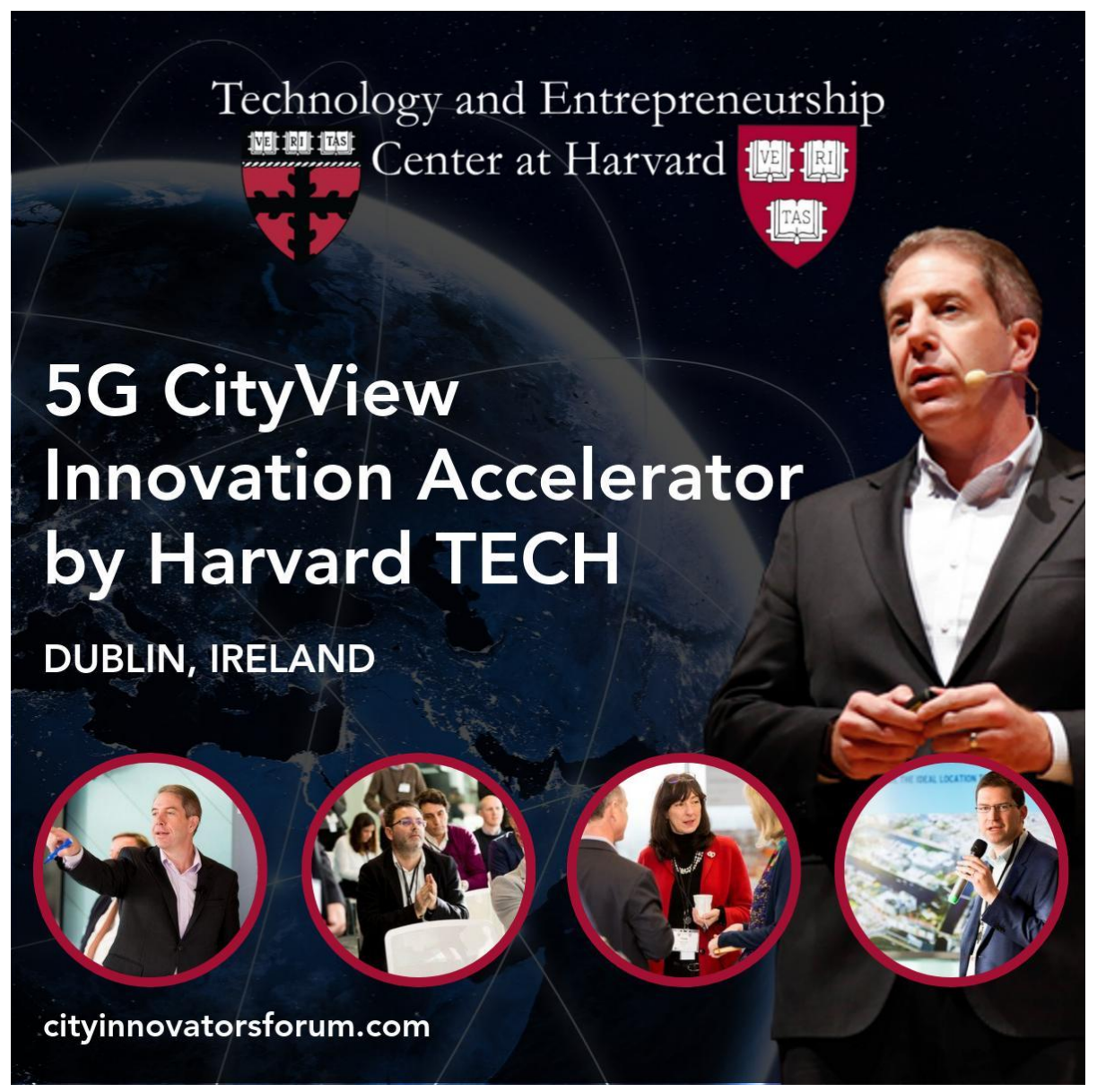




\section{Exhibit 11: Excerpts from DCC 5G Discussion Paper}

- Passive Neutral Host a.k.a Multiple Operator Antennas in one Small Cell

This involves a one-piece enclosure deployed with multiple operator equipment found inside. This means the only thing the operators are sharing is the small cell and not the radio spectrum. This can be utilised by a single small cell and supporting multiple MNO frequency bands.

This may require the design and deployment of new tailored smart poles and multi-operator cabinets - so there is an opportunity to align with street lighting upgrades across local authorities.

- Active Neutral Host a.k.a Spectrum-based sharing

This is where the provider has its own local radio resources (shared or dedicated) and network (access to spectrum) to host others as 'tenants'. This means the sharing happens on a core network level rather than at a small cell street level.

Source: DCC 5G Discussion Paper 


\section{Exhibit 12: National Broadband Plan Contract}

\section{Government signs off on contract for controversial $€ 3$ billion National Broadband Plan}

THE GOVERNMENT HAS signed off on the $€ 3$ billion National Broadband Plan contract at its weekly cabinet meeting today.

It comes after the European Commission granted State aid approval for the plan last week.

The Cabinet met this morning to facilitate the plan being signed off on ahead of an event to mark the occasion at a school in Wicklow later in the morning.

Speaking this morning, Taoiseach Leo Varadkar said:

"It is the biggest investment in rural Ireland ever and the most significant since rural electrification."

"An average of over 100 million euro in every local authority in the country" is to be invested in the infrastructural project."

Initially 300 broadband connection points will be set up in community settings such as GAA clubs, community centres and public libraries.

These hubs will provide free high-speed broadband to people living in rural areas until broadband is delivered to their homes.

Varadkar referred to the case of a young girl with an interest in coding who had to go to the carpark of her local supermarket to pick up Wi-Fi as it was so poor in her own home.

The National Broadband Plan is the government's plan to rollout high speed broadband to 1.1 million people living and working in the nearly 540,000 premises - including homes, schools, businesses and farms - where commercial operators will not commit to deliver the service.

\section{Opposition criticisms}

The plan, which has been beset by delays and setbacks, will see high-speed broadband being rolled out across the country within eight weeks.

Opposition parties have criticised the government for pressing ahead with the contract, calling on the broadband network to publicly owned, as the State is investing such a significant amount in the project.

However, Varadkar defended the signing of the contract today: 
"This contract means that every home, school, farm and business in Ireland will get access to high speed broadband. No part of the country will be left behind in securing the jobs and opportunities of the future."

Sinn Féin communications spokesperson David Cullinane today said that while rural broadband is a necessity, the government's plan is not the right option.

"The government should not be proceeding with this particular option. It is one that has received almost universal criticism - from political parties, Oireachtas committees, senior civil servants, and the industry itself," he said.

He said "there is nobody except Fine Gael who thinks this plan is a good idea".

Cullinane said that while rollout of broadband is needed in rural Ireland, it should not end up costing the State more than is necessary, stating:

"We won't even own it at the end - indeed, the network can be sold off after nine years."

Labour's Brendan Howlin said the government had no regard for public money, stating that they were "throwing money" at the broadband plan in a bid to get it over the line.

He said the Labour Party would be consulting legal experts to ascertain if the contract could be reneged on by the next party in government, if needed.

"Obviously we have to look at the detail of the contract once it is signed, whether it can be undone. I don't know the answer to that, we have to have a look at the details of the contract, but I do know that the perseverance of the government is bad public policy. And it just echoes again the expensive nature of the government. They have no regard for public money after the decade of difficulties the Irish people have gone through so they can throw money at broadband or they can throw money at the National Children's Hospital," he said.

Fianna Fáil's Stephen Donnelly said the government has failed in the entire broadband process, and stated that the delays in the rollout has been "appalling".

"I think everyone should be worried when government starts announcing big capital plans, right in the middle of a by-election," he said.

Donnelly said Fianna Fáil wants to now hear from the Department of Expenditure and Public Reform on what it thinks about the current plan, highlighting that the secretary general of the department has previously stated that it is not value for money.

The Wicklow TD said he believed the Irish people have "been led down the garden path" with the National Broadband Plan".

\section{Delays}


The signing of the contract does bring an end to the delays with the plan. National Broadband Ireland was awarded the contract for the project in May after a controversial bidding process which saw several leading bidders withdraw themselves from consideration.

It had been expected that a contract would be awarded last year but former communications minister Denis Naughten quit his post after revelations about a series of meetings with the head of the Granahan McCourt consortium David McCourt.

Granahan McCourt was the sole remaining bidder when it was granted preferred bidder status earlier this year.

In a statement today, Naughten said today's signing of the contract is "one of the defining days in the history of our country and will be the turning point for the revitalisation of rural Ireland".

The decision to sign off on the plan comes despite the Secretary General of the Department of Public Expenditure Robert Watt repeatedly urging the government not to proceed with the multi-billion euro project.

- With reporting by Christina Finn, Hayley Halpin and Press Association 